\title{
Effect of compost formulation and postharvest management on quality parameters of button mushroom
}

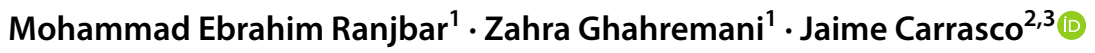

Received: 11 December 2018 / Accepted: 26 September 2019 / Published online: 9 October 2019

(c) The Author(s) 2019

\begin{abstract}
Purpose The main objective of the present study was to evaluate the effects of compost formulation made from agricultural by-products and thermal treatment of fresh mushrooms on the postharvest quality parameters.

Methods Quail manure was evaluated as an alternative ingredient to the broadly used chicken manure for compost preparation. In addition, the treatment of fresh mushrooms by hot water to extend shelf-life was tested. Quality parameters including color (browning due to microbial activity), cap opening and the weight loss (senescence) were evaluated.

Results The nature of the manure employed as base material in the substrate can affect the postharvest browning ratio of mushroom. However, no significant differences in $\Delta b$ value, weight loss or cap opening were noticed between two different substrates during storage of harvested mushrooms. The cap opening ratio was further retarded while applying thermal treatment to the mushrooms at $55^{\circ} \mathrm{C}$.

Conclusions The use of chicken manure as base material to prepare mushroom substrate reduces mushroom browning during storage compared to quail manure, although mushrooms from quail compost are whiter at picking. Postharvest treatment at $45^{\circ} \mathrm{C}$ for 4 min was the best to minimize the weight loss.
\end{abstract}

Keywords Compost formulation $\cdot$ Mushroom substrate $\cdot$ Postharvest properties $\cdot$ Thermal treatment

\section{Introduction}

Among cultivated edible mushrooms, the champignon or button mushroom [Agaricus bisporus (Lange) Imbach] is one of the most widely cultivated species and consumed worldwide (Karakurt and Toka 2016; Carrasco et al. 2018). Their consumption is gradually increasing due to their appreciated flavor, the interesting nutritional value, with similar protein content to meat or eggs (Liu et al. 2015), and low calories content, which is comparable to vegetables (Wani et al. 2010). It is noteworthy that mushrooms have a shelf-life shorter than most ready-to-use vegetables due to their rapid respiratory rate and the absence of

Jaime Carrasco

jaime.carrasco@plants.ox.ac.uk

1 Horticultural Department, University of Zanjan, Zanjan, Iran

2 Centro Tecnológico de Investigación del Champiñón de La Rioja (CTICH), Autol, Spain

3 Department of Plant Sciences, University of Oxford, Oxford, UK a physical barrier to prevent water loss or microbial attacks (Mohapatra et al. 2010). One of the symptomatic evidences of button mushroom decay is cap browning, associated with the activity of the enzyme tyrosinase (enzyme related to melanin biosynthesis), which belong to the polyphenol oxidase (PPO) enzyme family (Nerya et al. 2006). Different methods to extend shelf-life and reduce the contamination levels have been reported, for instance, effective packing, irradiation of carpophores or the application of tomato juice (Rai and Arumuganathan 2008; Srivastava et al. 2010). The treatment of fresh vegetables by hot water can inhibit biochemical pathways involved in ripening and spoilage while retarding the activity of cell wall, degrading enzymes and disordering the ethylene synthesis enzymes involved in ripening and fruit decay (Paull and Chen 2000; Safdar Khan 2009). Several substrate formulations can be used to grow Agaricus bisporus. Cereal straws (rice, wheat, oat and barley), horse manure and chicken manure and industrial byproducts such as sugarcane bagasse are the most important ingredients for substrate formulation (Andrade et al. 2008). The button mushroom is an heterotroph that obtain the nutrients required from the selective substrate where it grows; 
therefore, substrate design and formulation is among the most relevant parameters for mushroom production because it directly exerts mushroom nutrition and ultimately conditions the mycelium growth, basidiome development and shelf-life of the mushroom in postharvest (Ranjbar and Olfati 2017; Ranjbar et al. 2017). The aim of the current study was to evaluate the effects of compost formulation, the period of storage and the treatment of fresh mushrooms by hot water on some postharvest properties such as color, loss of water content and cap opening ratio (senescence).

\section{Materials and methods}

The experimental trial was conducted in a commercial mushroom farm, at Babolsar and University of Zanjan, Iran, between March and September 2018. Two experiments were accomplished during this study to assess the postharvest properties of the button mushrooms collected: first experiment was conducted to examine the effect of different compost formulations using quail manure and chicken manure, respectively, as base ingredients; the second experiment was to evaluate the treatment of fresh mushrooms by hot water to extend shelf-life.

\section{Compost and spawn preparation}

Compost was prepared from raw materials corresponding to wheat straw, sugarcane bagasse and selected manure type. The straw was pre-wetted with water and turned diary along 8 days before forming windrows. Phase I of composting process was developed onto concrete floor provided with natural ventilation in open sides. Windrows of $20 \mathrm{~cm}$ in height of straw were disposed, on top of which a layer of sugarcane bagasse was applied to build into a $1.8 \mathrm{~m}$ height $\times 1.8 \mathrm{~m}$ width. Nitrogen supplements such as urea and the different kind of manure were levelly added to the windrow. The mixture was diary turned and manually watered to maintain $70-75 \%$ of moisture. Up to 5 turns were undertaken for a 12-day phase I period. Subsequently, compost was transferred to perforated plastic boxes of $56.5-\mathrm{cm}$ length, $46.5-\mathrm{cm}$ width, and $28.5-\mathrm{cm}$ height to perform phase II composting. The boxes were disposed randomly in a chamber where pasteurization $\left(6 \mathrm{~h}\right.$ at $\left.61 \pm 1{ }^{\circ} \mathrm{C}\right)$ and conditioning (11 days at $48 \pm 1{ }^{\circ} \mathrm{C}$ ) of the compost mass were carried out. Table 1 shows physicochemical characterisation of the manufactured substrate compost and Table 2 shows average nutrient compositions of chicken and quail manures.

Spawn grain was prepared from mother culture by mixing 2:1 proportion of boiled wheat grain and sawdust, amended with $\mathrm{CaCO}_{3}$ at $0.2 \%$, while keeping the moisture content around $65 \%$. An amount of 250-g mixture was introduced in polypropylene bags. The bags were subsequently sterilized
Table 1 Moisture, carbon and nitrogen contents, $C / N$ and $\mathrm{pH}$ of compost prepared with chicken and quail manures

\begin{tabular}{lcl}
\hline & Chicken manure compost & $\begin{array}{l}\text { Quail } \\
\text { manure } \\
\text { compost }\end{array}$ \\
\hline Moisture & 70.6 & 71.2 \\
Carbon & 40.2 & 41 \\
Nitrogen & 2.2 & 2.4 \\
$C / N$ & 18.27 & 17.08 \\
$\mathrm{pH}$ & 6.8 & 6.5 \\
\hline
\end{tabular}

Table 2 Average percentage of NPK compositions of chicken and quail manures

\begin{tabular}{lllll}
\hline Manure type & Total $N$ & $\begin{array}{l}\text { Ammo- } \\
\text { nium } \\
(\mathrm{NH}-\mathrm{N})\end{array}$ & Phosphorus (P) & Potassium (K) \\
\hline Chicken & 1.17 & 0.45 & 0.77 & 0.49 \\
Quail & 4.96 & 0.34 & 1.08 & 1.07 \\
\hline
\end{tabular}

for $1 \mathrm{~h}$ at $120^{\circ} \mathrm{C}$ under $1 \mathrm{~kg} / \mathrm{cm}^{2}$ pressure in an autoclave. Inoculation of the compost was manually conducted; $1.5 \%$ of $A$. bisporus spawn was added to the compost. Polyethylene boxes filled with $12-12.5 \mathrm{~kg}$ of compost were internally lined with polyethylene plastic film punctured in the bottom. A random design for the boxes was disposed for the incubation of the spawned compost for 13 days at $22 \pm 1^{\circ} \mathrm{C}$.

\section{Cropping and post-harvest storage}

The peat-based casing soil employed was based on $80 \%$ peat $+20 \%$ perlite. 20 days before casing application, the $\mathrm{pH}$ was buffered to 7.0 by amending with calcium carbonate $\left(30 \mathrm{~kg} \mathrm{~m}^{-3}\right)$. The casing soil was pasteurized at $62{ }^{\circ} \mathrm{C}$ for $8 \mathrm{~h} .4 \mathrm{~cm}$ of casing soil was applied onto colonized compost and watered to keep moisture content around $70 \%$. The compost was covered with a transparent plastic, placed in darkness and incubated for 15 days at $22 \pm 1{ }^{\circ} \mathrm{C}$. After the casing soil was colonized (15 days at $22 \pm 1^{\circ} \mathrm{C}$ ), the transparent plastics applied to keep high moisture content were removed and environmental growing parameters were set up; temperature: $22 \pm 1{ }^{\circ} \mathrm{C}$ and relative humidity between 75 and $85 \%$. The first flush was harvested and then mushrooms were graded for size uniformity, color, appearance and ripeness. Graded mushrooms were initially washed with water to remove casing soil. A thermostatic bath machine (R. Espinar.S.L. model. BAE-2) was used to perform the hot water treatment by immersion method (Fig. 1). After hot water treatment, mushrooms were allowed to dry at room temperature with the aid of fan winding and absorbent paper. Mushrooms 


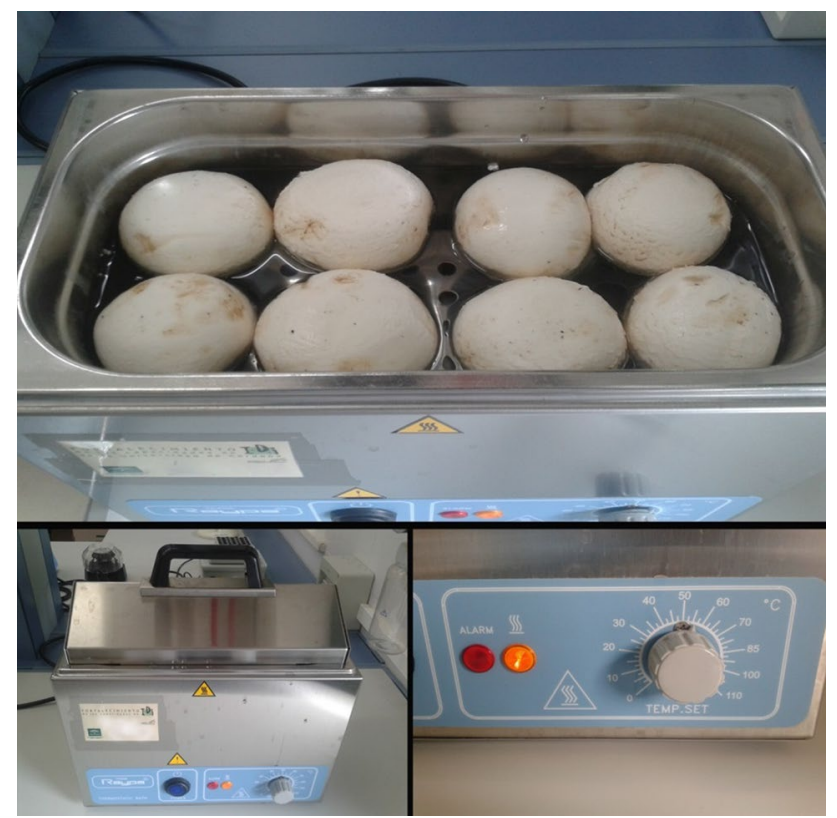

Fig. 1 Hot water treatment of mushrooms by thermostatic bath device

were then stored in refrigerator at $4{ }^{\circ} \mathrm{C}$ immediately after full drying and packing up in commercially used packages (PET).

\section{Tested treatments}

In the first experiment, quail manure was used as alternative to chicken manure in compost preparation. The effects of storage at three levels: after 7 days of storage (first week, treatment in the 7th day-treatment in day 0), from 7 th to 14th day of storage (between first and second week, treatment in the 14th day-treatment in the 7th day) and after 14 days of storage (after the second week, treatment after the 14th day-treatment in day 0) and manure at two levels: chicken manure and quail manure were evaluated on postharvest properties of the mushrooms. Besides, the effect of manure on mushrooms color was evaluated immediately after harvest.

In the second experiment, the effect of hot water treatment on postharvest properties of button mushroom was evaluated. The treatments included: (a) hot water at four levels: $25{ }^{\circ} \mathrm{C}$ (control-room temperature), $35{ }^{\circ} \mathrm{C}, 45{ }^{\circ} \mathrm{C}$ and $55^{\circ} \mathrm{C}$; (b) length of hot water treatment at five levels: 0 min (control-quick dipping just for a few seconds), $2 \mathrm{~min}, 4 \mathrm{~min}, 6 \mathrm{~min}$ and $8 \mathrm{~min}$; and (c) extension of storage at three levels: after 7 days of storage, after 14 days of storage and from 7 th to 14 th days of storage.

\section{Quality assessment analysis}

Weight loss expressed as the percentage of weight loss with respect to the initial weight by registering mushroom weight before and after the storage period. Weight loss $(\%)=\left(W_{0}-W_{\mathrm{f}}\right) / W_{0} \times 100 ;\left(W_{0}\right.$ is weight of the mushrooms before storage, $W_{\mathrm{f}}$ is the fweight registered after the storage period) (Lagnika et al. 2011).

Color To investigate the color change in harvested basidiomes, the following procedure based on three basic components, illumination source, photographic camera and computer with image software, was used: (1) illumination was provided by four fluorescent (white) lamps disposed in a dark wooden box, in angle of $45^{\circ}$ and $45 \mathrm{~cm}$ above the sample (2) A color digital camera located vertically $25 \mathrm{~cm}$ over the sample was employed with the iris operated in manual mode, lens aperture of 4 and speed of $1 / 10 \mathrm{~s}$ (no zoom, no flash). (3) Image J software (National Institutes Health, Bethesda, MD, USA) version $1.40 \mathrm{~g}$ to reduce background's contrast and the conversion of RGB chromatic space into $L^{*} a^{*} b^{*}$ units was performed since this is a device-independent methodology that provides stable color measurements independent of the input or output. $L=0$ yields black and $L=100$ indicates white; negative $a$ values indicate green while positive values indicate red; negative $b$ values indicate blue and positive $b$ values indicate yellow. The following applied to calculate $\Delta L$ value (reduction rate), $\Delta a$ value (increasing rate) and $\Delta b$ value (increasing rate) respectively was: $x(\%)=\left(n_{1}-n_{0} / n_{0}\right) \times 100$; $(x$ is $L, a$ or $b$ value reduction-increasing rate respectively, $n_{1}$ is the initial $L, a$ or $b$ value of the mushrooms, $n_{0}$ is the final $L, a$ or $b$ value of the mushrooms after storage respectively) (Mohebbi et al. 2012).

Cap opening Percentage of open cap mushrooms was calculated as: Open caps $(\%)=\left(N_{\mathrm{oc}} \times 100\right) / N_{\mathrm{t}} ;\left(N_{\mathrm{t}}\right.$ is the total number of mushrooms, $N_{\mathrm{oc}}$ is the number of open cap mushrooms) (Jiang et al. 2011).

\section{Experimental design and data analysis}

A factorial experiment was arranged in a completely randomized design with six treatments and three replicates for the first experiment. The second experiment comprised 60 treatments replicated 3 times. The results were analyzed using the Minitab 16 software and means were compared using Tukay's test (HSD) $(P \leq 0.05)$. 
Table 3 Effect of manure employed in compost preparation on color parameters of button mushroom immediately after harvest

\begin{tabular}{llll}
\hline Manure & $\begin{array}{l}\text { L value after } \\
\text { harvest }\end{array}$ & $\begin{array}{l}a \text { value after } \\
\text { harvest }\end{array}$ & $\begin{array}{l}b \text { value } \\
\text { after } \\
\text { harvest }\end{array}$ \\
\hline Chicken & $66.50 \mathrm{~b}^{*}$ & $-7.73 \mathrm{a}$ & $1.01 \mathrm{a}$ \\
Quail & $70.53 \mathrm{a}$ & $-8.73 \mathrm{a}$ & $1.51 \mathrm{a}$ \\
\hline
\end{tabular}

*Values in columns for same variable followed by the same letter are not significantly different according to Tukey's (HSD) test $(P \leq 0.01)$

\section{Results and discussion}

\section{First experiment}

The measured properties were conditioned by the duration of storage (Table 4). The nature of the manure used in the substrate affected mushroom color change ( $\Delta L$ value and $\Delta a$ value) (Table 4). Harvested mushrooms from quail manure compost showed higher $L$ value (70.53) compared to chicken manure (66.50) compost in day 0 (immediately after harvest) (Table 3), but the browning ratio in mushrooms cultivated with compost based on chicken manure was lower than those cultivated with quail manure during storage period (Table 5) (chicken manure showed lower $L$ value reduction and $\Delta a$ compared to quail manure. According to Gupta and Bhat (2016), the browning index of mushrooms supposes a change in color of mushrooms, influenced by the $L$ value decrease with $a$ and $b$ value increase, which ends up into a raise of the browning index. Our findings are consistent with the literature; the chemical, functional and sensorial characteristics of mushrooms have been reported to be influenced by the nature of the substrates employed in mushroom cultivation (Oyetayo and Ariyo 2013). The substrate has a direct influence on mineral compositions of the carpophores, because the fungal mycelium is in contact with the compost as nutrient source from which it withdraws essential elements. The protein and other nutrient contents of basidiomes cultivated on different agrowastes show significant variations. For instance, nitrogen is essential for synthesis of protein in mushroom fruiting bodies, and the amount of nitrogen in the substrate can directly affect the amount of protein in the fruiting bodies (Ranjbar and Olfati 2017; Ranjbar et al. 2017). Since proteins are very sensitive to oxidative modifications, different protein levels in the mushrooms are subjected to a number of reactions related to the environmental factors during postharvest (Oyetayo and Ariyo 2013). In this study, we can correlate the different $L$ value observed in harvested mushrooms from different substrates with the amount of nitrogen measured in the substrates $(1.17 \%$ of total $N$ and $0.45 \%$ ammonium $N$ in chicken manure against $4.96 \%$ of total $N$ and $0.35 \%$ ammonium $N$ in quail manure) (Table 2).

A value increased 15.4 times after 14 days of storage compared to 7 days of storage (Table 5). The percentage of weight loss of mushrooms was affected by the duration of
Table 4 Effect of manure type, duration of storage and their interaction on measured characteristics in the color of $\Delta L$, reduction rate value, $\Delta a$, increasing rate value, and $\Delta b$, increasing rate value
Table 5 Effect of the manure formulation employed and the period of storage on postharvest quality (color change, weight loss and cap opening

\begin{tabular}{lrlllll}
\hline Source & $d f$ & \multicolumn{2}{l}{ Mean Square } & & \\
\cline { 2 - 6 } & & $\Delta L$ & $\Delta a$ & $3 b$ & Weight loss & Cap opening \\
\hline Ds & 2 & 192.93 & $10,468.3$ & 3822 & 398.87 & 256.22 \\
$M$ & 1 & 107.36 & 909.88 & 2.39 & 0.06 & 2.05 \\
Ds $\times M$ & 2 & 14.63 & 164.76 & 394.34 & 0.22 & 0.28 \\
Error & 10 & 7.10 & 81.00 & 200.6 & 0.26 & 4.16 \\
CV (\%) & & 1.71 & 9.22 & 8.61 & 6.2 & 6.8 \\
\hline
\end{tabular}

$D$ s duration of storage, $M$ manure

\begin{tabular}{lcllll}
\hline Variable & $\Delta L$ value (\%) & $\Delta a$ value $(\%)$ & $\Delta b$ value $(\%)$ & Weight loss (\%) & Cap opening (\%) \\
\hline Manure & & & & & \\
Quail & $14.74 \mathrm{a}$ & $60.44 \mathrm{a}$ & $58.49 \mathrm{a}$ & $8.02 \mathrm{a}$ & $37.65 \mathrm{a}$ \\
$\quad$ Chicken & $9.87 \mathrm{~b}$ & $46.22 \mathrm{~b}$ & $57.93 \mathrm{a}$ & $7.91 \mathrm{a}$ & $37.05 \mathrm{a}$ \\
Duration of storage & & & & & \\
After 7 days & $7.33 \mathrm{~b}$ & $5.19 \mathrm{~b}$ & $44.13 \mathrm{~b}$ & $7.60 \mathrm{~b}$ & $37 \mathrm{~b}$ \\
After 14 days & $18.48 \mathrm{a}$ & $80.00 \mathrm{a}$ & $87.43 \mathrm{a}$ & $16.29 \mathrm{a}$ & $64.75 \mathrm{a}$ \\
From 7 to 14 days & $11.13 \mathrm{~b}$ & $74.80 \mathrm{a}$ & $43.31 \mathrm{~b}$ & $8.69 \mathrm{~b}$ & $27.75 \mathrm{~b}$ \\
\hline
\end{tabular}

*Values in columns for same variable followed by the same letter are not significantly different according to Tukey's (HSD) test $(P \leq 0.01)$ 
storage (Table 4). According to Nones and Emond (2007), even when weight loss appears during storage regardless of the type of fruit or vegetable, the rate of water loss is highly dependent on the type of crop type and is greatly related to the morphology and physiology of the fruit or vegetable under analysis (Nones and Emond 2007). Weight loss of mushrooms raised by increasing the time of storage, and weight loss of mushrooms increased by $53.34 \%$ after 14 days of storage compared to the 7th day of storage. Cap opening rate increased by $42.86 \%$ at 14 th day of storage compared to 7 th day of storage (Table 5).

\section{Second experiment}

\section{$L$ value reduction rate}

The largest reduction rate of $L$ value after 7 days of storage was recorded at hot water treatment $T=55^{\circ} \mathrm{C}$ for $8 \mathrm{~min}$ (16.10\%). The best treatment to minimize $L$ value reduction after 14 days of storage was $T=45{ }^{\circ} \mathrm{C}$ for $4 \min (0.46 \%)$ (Table 7). Our findings with respect to the effect of hot water treatment on mushroom discoloration are in line with those reported by Das et al. (2010) and Rajarathnam et al. (1983). Rajarathnam et al. (1983) observed an increase in activities of $o$-diphenol oxidase, proteases and free amino acids, and a fall in total phenols, which might have resulted in the increasing of mushroom discoloration along the period of storage. On the other hand, Das et al. (2010) reported that gradual change in color of mushroom from white to black occurs with the duration of storage and the treatment with hot water, by disordering of the ethylene synthesis enzymes, can inhibit some biochemical pathways involved in discoloration of mushrooms. Besides, in a similar research, heat treatments have been shown to prevent the wound-induced synthesis of phenols by inhibiting phenylalanine ammonia lyase enzyme (PAL) activity and, thus, reducing browning development in fresh-cut vegetables such as celery (Viña and Chaves 2008) and lettuce (Loaiza-Velarde and Saltveit 2001).

\section{$\Delta b$ value (increasing rate)}

Hot water treatment showed significant variation in the $\Delta b$ color value during storage (Table 6). According to the results, the highest $\Delta b$ was obtained in hot water treatment at $45^{\circ} \mathrm{C}$ for 4 min after 14 days of storage (126.87\%) (Table 7).

\section{$a$ value increasing rate and percentage of cap opening and weight loss}

The highest $\Delta a$ value was recorded in hot water treatment at $25^{\circ} \mathrm{C}$ (control) after 14 days of storage $(712.48 \%$ ) (Table 8 ). The best treatment to minimize weight loss was for $4 \mathrm{~min}$ $(7.23 \%)$ and on the other hand, the best temperature of treatment to reduce weight loss in basidiomes was $45^{\circ} \mathrm{C}(5.82 \%)$ (Table 9). The result of this study is similar to the findings reported by Fan et al. (2008). They reported that hot water treatment of blueberries resulted in minor weight loss during the 4-week storage period, regardless of treatment duration, than in control fruit. The water uptake throughout the treatment has been associated with this effect (Fan et al. 2008). As reported by Lum and Norazira (2011), submerging fruit and vegetable would facilitate the water to enter the fruit cells. Thus, the fruit weight would increase and the fruit weight loss percentage would decrease during storage (Lum and Norazira 2011). According to our results, the best temperature of treatment to reduce open caps was $55^{\circ} \mathrm{C}(20.1 \%)$ after 7 and 14 days of storage (Table 10). Cap opening, associated with mushroom senescence, deeply affects the market acceptability since this biological feature damages the product during postharvest (Rai and Arumuganathan 2008). Both aging and the loss of water content are directly correlated with the percentage of open caps (Jiang et al. 2011).
Table 6 Effect of postharvest treatment (period of storage, temperature, duration of hot water treatment and the interactions on measured characteristics) on the measured parameters (color variation, weight loss and cap opening ratio)

\begin{tabular}{lrccccl}
\hline Source & $d f$ & \multicolumn{3}{l}{ Mean square } & & \\
\cline { 2 - 6 } & & $\Delta L$ value (\%) & $\Delta a$ value $(\%)$ & $\Delta b$ value (\%) & Weight loss (\%) & Cap opening (\%) \\
\hline Ds & 2 & $1753.8^{* *}$ & $4.19 \mathrm{~ns}$ & $1417.52^{* *}$ & $9.02 \mathrm{~ns}$ & $0.11 \mathrm{~ns}$ \\
$T$ & 3 & $1006.20^{* *}$ & $12.42 \mathrm{~ns}$ & $247.74^{* *}$ & $209.65^{* *}$ & $0.35 \mathrm{~ns}$ \\
Dt & 4 & $61.06^{* *}$ & $33.72^{* *}$ & $17.05^{* *}$ & $69.81^{* *}$ & $1.05^{* *}$ \\
Ds $\times T$ & 6 & $152.49^{* *}$ & $26.49^{* *}$ & $116.23^{* *}$ & $7.02 \mathrm{~ns}$ & $1.18^{* *}$ \\
Ds $\times$ Dt & 8 & $59.01^{* *}$ & $4.15 \mathrm{~ns}$ & $7.71^{*}$ & $12.78 \mathrm{~ns}$ & $0.27 \mathrm{~ns}$ \\
$T \times \mathrm{Dt}$ & 12 & $95.53^{* *}$ & $6.02 \mathrm{~ns}$ & $11.17^{* *}$ & $12.73 \mathrm{~ns}$ & $0.30 \mathrm{~ns}$ \\
Ds $\times T \times$ Dt & 24 & $58.45^{* *}$ & $5.61 \mathrm{~ns}$ & $8.70^{* *}$ & $6.72 \mathrm{~ns}$ & $0.10 \mathrm{~ns}$ \\
Error & 118 & 15.59 & 7.89 & 4.11 & 14.65 & 0.16 \\
$(\%) \mathrm{CV}$ & & 6.16 & 8.42 & 8.32 & 12.02 & 6.1 \\
\hline
\end{tabular}

$D s$ duration of storage, $T$ temperature, $D t$ duration of treatment ns, **, * no significant or significant at $P \leq 0.01$ and $P \leq 0.05$, respectively 
Table 7 Effect of interaction between duration of storage, temperature and duration of hot water treatment on $\Delta L$, reduction rate value and $\Delta b$, increasing rate value

\begin{tabular}{|c|c|c|c|c|c|c|c|c|c|}
\hline \multirow[t]{2}{*}{$\overline{T\left({ }^{\circ} \mathrm{C}\right)}$} & \multirow[t]{2}{*}{ Dt (min) } & \multicolumn{3}{|l|}{$\Delta L$ value $(\%)$} & \multirow[t]{2}{*}{$T\left({ }^{\circ} \mathrm{C}\right)$} & \multirow[t]{2}{*}{ Dt (min) } & \multicolumn{3}{|l|}{$\Delta b$ value $(\%)$} \\
\hline & & After 7 days & After 14 days & From 7 to 14 days & & & After 7 days & After 14 days & $7-14$ days \\
\hline \multirow[t]{5}{*}{25} & 0 & $3.11 \mathrm{j}^{*}$ & $6.93 p$ & $3.82 \mathrm{ij}$ & \multirow[t]{5}{*}{25} & 0 & $8.25 p$ & $25.88 \mathrm{~m}$ & $17.63 \mathrm{i}$ \\
\hline & 2 & $2.83 \mathrm{k}$ & $6.04 \mathrm{r}$ & $3.21 \mathrm{jk}$ & & 2 & $6.56 q$ & 30.711 & $24.15 \mathrm{~h}$ \\
\hline & 4 & $3.88 \mathrm{f}$ & $7.78 n$ & $3.90 \mathrm{ij}$ & & 4 & $9.90 \mathrm{o}$ & 29.741 & $19.84 \mathrm{i}$ \\
\hline & 6 & $5.91 \mathrm{e}$ & 9.141 & $3.21 \mathrm{jk}$ & & 6 & 21.411 & $35.27 \mathrm{k}$ & $13.86 \mathrm{j}$ \\
\hline & 8 & $3.81 \mathrm{~g}$ & $8.73 \mathrm{~m}$ & $4.92 \mathrm{~h}$ & & 8 & $18.25 \mathrm{~m}$ & $20.63 n$ & $2.38 \mathrm{~m}$ \\
\hline \multirow[t]{5}{*}{35} & 0 & $1.26 \mathrm{n}$ & $12.35 \mathrm{i}$ & $11.09 \mathrm{e}$ & \multirow[t]{5}{*}{35} & 0 & $53.79 \mathrm{f}$ & $61.16 \mathrm{i}$ & 7.371 \\
\hline & 2 & $0.46 \mathrm{pq}$ & $10.16 \mathrm{k}$ & $9.64 f$ & & 2 & $82.70 \mathrm{~b}$ & $110.78 \mathrm{c}$ & $28.08 \mathrm{~g}$ \\
\hline & 4 & $6.35 \mathrm{~d}$ & $10.60 \mathrm{j}$ & $4.25 \mathrm{hi}$ & & 4 & $91.42 \mathrm{a}$ & $99.47 d$ & $8.05 \mathrm{kl}$ \\
\hline & 6 & 1.781 & $26.44 d$ & $24.66 \mathrm{~b}$ & & 6 & $67.00 \mathrm{~d}$ & $97.46 \mathrm{de}$ & $30.46 \mathrm{fg}$ \\
\hline & 8 & 0.920 & $26.94 b$ & $26.02 \mathrm{a}$ & & 8 & $51.31 \mathrm{~g}$ & $97.00 \mathrm{e}$ & $45.69 \mathrm{~cd}$ \\
\hline \multirow[t]{5}{*}{45} & 0 & $3.65 \mathrm{~h}$ & $6.72 q$ & $2.62 \mathrm{k}$ & \multirow[t]{5}{*}{45} & 0 & $8.23 \mathrm{p}$ & $26.64 \mathrm{~m}$ & $18.41 \mathrm{i}$ \\
\hline & 2 & $0.51 \mathrm{p}$ & $16.24 \mathrm{~g}$ & $15.73 d$ & & 2 & $22.33 k$ & $75.00 \mathrm{~h}$ & $52.67 \mathrm{~b}$ \\
\hline & 4 & $0.44 q$ & $0.46 \mathrm{~s}$ & 0.021 & & 4 & $75.18 \mathrm{c}$ & $126.87 \mathrm{a}$ & $51.69 \mathrm{~b}$ \\
\hline & 6 & $0.45 \mathrm{pq}$ & $6.94 p$ & $6.49 \mathrm{~g}$ & & 6 & $15.02 \mathrm{n}$ & $120.03 b$ & $105.01 \mathrm{a}$ \\
\hline & 8 & $0.46 \mathrm{pq}$ & $24.76 \mathrm{e}$ & $24.30 \mathrm{~b}$ & & 8 & $50.74 \mathrm{~g}$ & $96.90 \mathrm{e}$ & $46.16 \mathrm{c}$ \\
\hline \multirow[t]{5}{*}{55} & 0 & $3.41 \mathrm{i}$ & $7.38 \mathrm{o}$ & $3.97 \mathrm{ij}$ & \multirow[t]{5}{*}{55} & 0 & $35.44 \mathrm{i}$ & $46.49 \mathrm{j}$ & $11.05 \mathrm{jk}$ \\
\hline & 2 & $12.62 \mathrm{~b}$ & $17.04 \mathrm{f}$ & 4.42hi & & 2 & $60.06 \mathrm{e}$ & $93.00 \mathrm{f}$ & $32.94 \mathrm{f}$ \\
\hline & 4 & $1.66 \mathrm{~m}$ & $12.78 \mathrm{~h}$ & $11.12 \mathrm{e}$ & & 4 & 21.411 & $27.24 \mathrm{~m}$ & 5.831 \\
\hline & 6 & $9.68 \mathrm{c}$ & $26.52 \mathrm{c}$ & $16.84 \mathrm{c}$ & & 6 & $34.59 \mathrm{j}$ & $72.93 \mathrm{~h}$ & $38.34 \mathrm{e}$ \\
\hline & 8 & $16.10 \mathrm{a}$ & $30.79 \mathrm{a}$ & $14.69 \mathrm{~d}$ & & 8 & $36.23 \mathrm{~h}$ & $79.23 \mathrm{~g}$ & $43.00 \mathrm{~d}$ \\
\hline
\end{tabular}

$T$ temperature of treatment, $D t$ duration of treatment

*Values in columns followed by the same letter are not significantly different, $P \leq 0.01$, Tukey's (HSD) test

Table 8 Effect of duration of treatment (Dt, min) and interaction between duration of storage (days) and temperature of treatment $\left(T,{ }^{\circ} \mathrm{C}\right)$ on a value increasing rate

\begin{tabular}{llllll}
\hline$T\left({ }^{\circ} \mathrm{C}\right)$ & Storage (day) & & & \\
\cline { 2 - 6 } & After 7 days & After 14 days & From 7 to 14 days & Dt $(\mathrm{min})$ & $\Delta a(\%)$ \\
\hline 25 & $73.89 \mathrm{efg}^{*}$ & $712.48 \mathrm{a}$ & $638.58 \mathrm{ab}$ & 0 & $221 \mathrm{c}$ \\
35 & $11.93 \mathrm{~g}$ & $389.55 \mathrm{~cd}$ & $377.71 \mathrm{~cd}$ & 2 & $219.06 \mathrm{c}$ \\
45 & $5.17 \mathrm{~g}$ & $525.64 \mathrm{abc}$ & $468.26 \mathrm{bc}$ & 4 & $568.43 \mathrm{a}$ \\
55 & $31.25 \mathrm{fg}$ & $240.64 \mathrm{de}$ & $209.39 \mathrm{def}$ & 6 & $341.66 \mathrm{~b}$ \\
& & & & 8 & $216.66 \mathrm{c}$ \\
\hline
\end{tabular}

$T$ temperature of treatment

*Values in columns followed by the same letter are not significantly different, $P \leq 0.01$, Tukey's (HSD) test
Table 9 Effect of temperature of treatment $\left(T,{ }^{\circ} \mathrm{C}\right)$ and duration of treatment $(\mathrm{Dt}, \mathrm{min})$ on weight loss percent

\begin{tabular}{llll}
\hline$T\left({ }^{\circ} \mathrm{C}\right)$ & $\begin{array}{l}\text { Weight loss per- } \\
\text { cent }(\%)\end{array}$ & Dt (min) & Weight loss $(\%)$ \\
\hline 25 & $10 \mathrm{a}^{*}$ & 0 & $9.90 \mathrm{a}$ \\
35 & $10.38 \mathrm{a}$ & 2 & $7.50 \mathrm{~b}$ \\
45 & $5.82 \mathrm{~b}$ & 4 & $7.23 \mathrm{~b}$ \\
55 & $6.25 \mathrm{~b}$ & 6 & $8.03 \mathrm{~b}$ \\
& & 8 & $10.10 \mathrm{a}$ \\
\hline
\end{tabular}

$T$ temperature of treatment, $D t$ duration of treatment

*Values in columns followed by the same letter are not significantly different, $P \leq 0.01$, Tukey's (HSD) test

\section{Conclusion}

Harvested mushrooms from quail manure compost were whiter (showed higher $L$ value) compared to chicken manure compost immediately after harvest. However, those picked from chicken manure compost preserved whiteness for longer storage time than the ones cultivated on quail manure compost. The best hot water treatment to prevent weight loss of mushrooms was for $4 \mathrm{~min}$ at $45^{\circ} \mathrm{C}$, while the treatment of 4-6 min at $55^{\circ} \mathrm{C}$ was the most effective to retard cap opening, and therefore mushroom decay during storage. 
Table 10 Effect of duration of treatment (Dt, min) and interaction between duration of storage (days) and temperature of treatment $\left(\mathrm{T},{ }^{\circ} \mathrm{C}\right)$ cap opening percent $(\%)$

\begin{tabular}{|c|c|c|c|c|c|}
\hline \multirow[t]{2}{*}{$T\left({ }^{\circ} \mathrm{C}\right)$} & \multicolumn{5}{|l|}{ Storage (day) } \\
\hline & After 7 days & $\begin{array}{l}\text { After } \\
14 \text { days }\end{array}$ & $\begin{array}{l}\text { From } \\
7 \text { to } \\
14 \text { days }\end{array}$ & $\mathrm{Dt}(\min )$ & $\begin{array}{l}\text { Cap open- } \\
\text { ing percent } \\
(\%)\end{array}$ \\
\hline 25 & $65.5 \mathrm{a}^{*}$ & $65.5 \mathrm{a}$ & Of & 0 & $38.47 \mathrm{a}$ \\
\hline 35 & $37.77 \mathrm{~b}$ & $38.88 \mathrm{~b}$ & $1.11 \mathrm{f}$ & 2 & $37.77 \mathrm{a}$ \\
\hline 45 & $32.22 \mathrm{~d}$ & $34.92 \mathrm{c}$ & $2.7 f$ & 4 & $23.81 \mathrm{c}$ \\
\hline \multirow[t]{2}{*}{55} & $20.1 \mathrm{e}$ & $20.1 \mathrm{e}$ & Of & 6 & $23.81 \mathrm{c}$ \\
\hline & & & & 8 & $26.92 \mathrm{~b}$ \\
\hline
\end{tabular}

$T$ temperature of treatment, $D t$ duration of treatment

*Values in columns followed by the same letter are not significantly different, $P \leq 0.01$, Tukey's (HSD) test

Open Access This article is distributed under the terms of the Creative Commons Attribution 4.0 International License (http://creativeco mmons.org/licenses/by/4.0/), which permits unrestricted use, distribution, and reproduction in any medium, provided you give appropriate credit to the original author(s) and the source, provide a link to the Creative Commons license, and indicate if changes were made.

\section{References}

Andrade M, Zied D, Marli Minhoni T, Filho J (2008) Yield of four Agaricus bisporus strains in three compost formulations and chemical composition analyses of the mushrooms. Braz J Microbiol 39:593-598. https://doi.org/10.1590/S1517-83822008000300034

Carrasco J, Zied D, Pardo J, Preston G, Pardo-Giménez A (2018) Supplementation in mushroom crops and its impact on yield and quality. AMB Express 8:146. https://doi.org/10.1186/s1356 8-018-0678-0

Das PK, Hassan MK, Akhther N (2010) Efficacy of washing and postharvest treatments on shelf life and quality of oyster mushroom. Prog Agric 21(1 \& 2):21-29. https://doi.org/10.3329/pa.v21i1 $-2.16745$

Fan L, Forney CF, Song J, Doucette D, Jordan MA, Mcrae KB, Walker BA (2008) Effect of hot water treatments on quality of highbush blueberries. J Food Sci 73(6):292-297. https://doi.org/10.111 1/j.1750-3841.2008.00838.x

Gupta P, Bhat A (2016) Efficacy of different washing treatments on quality of button mushrooms (A. bisporus). J Food Process Technol 7(6):590 (ISSN : 2157-7110)

Jiang T, Zheng X, Li J, Jing G, Cai L, Ying T (2011) Integrated application of nitric oxide and modified atmosphere packaging o improve quality of retention of button mushroom (Agaricus bisporus). Food Chem 126:1693-1699. https://doi.org/10.1016/j.foodc hem.2010.12.060

Karakurt Y, Toka D (2016) The influence of hot water and calcium chloride on the changes in ceel wall composition and activities of cell wall hydrolases during storage in Agaricus bisporus. J Food Biochem 40(2):220-226. https://doi.org/10.1016/j.foodc hem. 2010.12.060

Lagnika C, Zhang M, Wang S (2011) Effect of high argon pressure and modified atmosphere packaging on the white mushroom (Agaricus bisporus) physico-chemical and microbiological properties. J Food Nutr Res 50:167-176
Liu B, Huang Q, Cai H, Guo X, Wang T, Gui M (2015) Study of heavy metal concentrations in wild edible mushrooms in Yunnan Province, China. Food Chem 188:294-300. https://doi.org/10.1016/j. foodchem.2015.05.010

Loaiza-Velarde JG, Saltveit ME (2001) Heat shocks applied either before or after wounding reduce browning of lettuce leaf tissue. J Am Soc Hortic Sci 126:227-234. https://doi.org/10.21273/JASHS .126 .2 .227

Lum MS, Norazira MA (2011) Effects of hot water, submergence time and storage duration on quality of dragon fruit (Hylocereus polyrhizus). J Agric Sci 3(1):146-152 (E-ISSN 1916-9760)

Mohapatra D, Bira ZM, Kerry JP, Frías JM, Rodrigues FA (2010) Postharvest hardness and color evolution of white button mushrooms. J Food Sci 75(3):146-152. https://doi.org/10.111 1/j.1750-3841.2010.01518.x

Mohebbi M, Ansarifar E, Hasanpour N, Amiryousefi MR (2012) Suitability of Aloe Vera and Gum Tragacanth as edible coatings for extending the shelf life of button mushroom. Food Bioprocess Technol 5:3193-3202. https://doi.org/10.1007/s1194 7-011-0709-1

Nerya O, Ben-Arie R, Luzzatto T, Musa R, Khativ S, Vaya J (2006) Prevention of Agaricus bisporus postharvest browning with tyrosinase inhibitors. Postharvest Biol Technol 39(3):272-277. https:// doi.org/10.1016/j.postharvbio.2005.11.001

Nones C, Emond JP (2007) Relation between weight loss and visual quality of fruits and vegetables. Proc Fla State Hortic Soc 120:235-245 (ISSN 0886-7283)

Oyetayo VO, Ariyo OO (2013) Antimicrobial and antioxidant properties of Pleurotus ostreatus cultivated on different tropical woody substrates. J Waste Convers Bioprod Biotechnol 1(2):28-32

Paull RE, Chen NJ (2000) Heat treatment and fruit ripening. Postharvest Biol Technol 21:21-37. https://doi.org/10.1016/S0925 -5214(00)00162-9

Rai RD, Arumuganathan T (2008) Post-harvest technology of mushrooms. Yugantar Prakashan Pvt, New Delhi

Rajarathnam S, Bano Z, Patwardhan MV (1983) Post-harvest physiology and storage of the white Oyster mushroom (Pleurotus flavellatus). J Food Sci Technol 18(2):153-162. https://doi. org/10.1111/j.1365-2621.1983.tb00255.x

Ranjbar ME, Olfati JA (2017) Evaluation of substrate components on shiitake mushroom properties. Int J Veg Sci 23:145-150

Ranjbar ME, Olfati JA, Amani M (2017) Influence of enriched soaking water on shiitake (Lentinus edodes (Berk.) Singer) mushroom yield and properties. Acta Agric Slov 1093(5):555-560

Safdar Khan M (2009) Effect of post-harvest hot water and hot air treatments on quality and shelf life of tomato. Dissertation, University of Reading, UK

Srivastava A, Singh A, Raja R, Arunachalam KD (2010) Shelf-life extension of fresh mushrooms by application of Tomato. J Eng Sci Technol 2(5):783-786

Viña SZ, Chaves AR (2008) Effect of heat treatment and refrigerated storage on antioxidant properties of pre-cut celery (Apium graveolens L.). Int J Food Sci Technol 43:44-51. https://doi.org/10.111 1/j.1365-2621.2006.01380.x

Wani BA, Bodha RH, Wani AH (2010) Nutritional and medicinal importance of mushrooms. J Med Plant Res 4:2598-2604. https ://doi.org/10.5897/JMPR09.565

Publisher's Note Springer Nature remains neutral with regard to jurisdictional claims in published maps and institutional affiliations. 